\title{
Sanitising the City: Exploring Hegemonic Gentrification in London's Soho
}

\author{
by Erin Sanders-McDonagh, Magali Peyrefitte and Matt Ryalls \\ Middlesex University; Middlesex University; Middlesex University
}

Sociological Research Online, 21 (3), 3

<http://www.socresonline.org.uk/21/3/3.html>

DOI: $10.5153 /$ sro. 4004

Received: 1 Apr 2016 | Accepted: 26 Jun 2016 | Published: 31 Aug 2016

\begin{abstract}
This article will explore the gentrification of Soho, reflecting on ethnographic research undertaken in the area over the past fifteen months, to argue that the recent social, political, and economic changes in Soho must be understood in relation to private, marketized and globalized neoliberal capitalist forces. We argue that the changes to the area result in a heavily-weighted form of gentrification that works to actively and knowingly sanitize the city, removing 'undesirable' people and venues from the area. As such, we propose to define this process as 'hegemonic gentrification', and distinguish this from other forms of gentrification in order to understand the different processes that underpin these specific changes, and more broadly, it allows us to problematize these changes as regards to the 'right to the city', and to expand current understandings in a way that allows for a more nuanced analysis of urban gentrification and its impacts within neolibreral capitalism.
\end{abstract}

Keywords: Gentrification, Urban, London, Rights, Hegemony, Soho

\section{Introduction}

1.1 We start this article by exploring the specificities of gentrification in Soho, an area we argue is increasingly being shaped by global neoliberal capitalism into an enclave for the super-rich, often excluding marginalized or 'undesirable' people and venues from the area as a result. This paper, reflecting on ethnographic research carried out in Soho over the past fifteen months, adds to existing debates on the nature gentrification by using Soho as an example of what we call hegemonic gentrification, a process of social change we argue results in the sanitization of urban spaces. We suggest that hegemonic gentrification is distinguishable from other forms of gentrification, and we hope that this paper will contribute to current debates around neoliberal capitalism and the 'right to the city' (Marcuse 2012; Schmid 2012).

1.2 For readers who may be unfamiliar with the area, Soho is centrally located in London in between the commercial arteries of Oxford Street and Regent Street, the West End Theatres in Covent Garden, and the lively atmosphere of Leicester Square. Its central location has meant that residential properties here have been much more expensive compared to outer boroughs; according to UK property website Rightmove, the average property price in Soho is over $£ 1.5$ million (rightmove 2016). Planning and zoning of the area meant that until very recently, there were far more office and retail spaces than residences, although there were a number of social housing blocks for low-income residents (provided by a range of Housing Associations as well as Westminster and Camden Councils). With a more flexible legislation the council is increasingly permitting for a change from office to residential use which in turn has an effect on the prices of the real estate in the area[1]. Soho has also been known as a 'creative' space, with fashion students from Central St Martins (part of the University of Arts London) buying fabric from the stalls at the local Berwick Street Market, mixing with jazz musicians who played at Ronnie Scotts, and mingling with the sex workers and strippers near Walkers Court. Judith Walkowitz (2012) notes that Soho has long been a space of transgression, and from the start of the $20^{\text {th }}$ century its reputation for being bohemian and cosmopolitan has been firmly established. While the area has been socially mixed, it would be difficult to argue that it has been a 'working-class' neighbourhood in the past fifty years (and certainly not in 
the same way that areas in the east or south of London were working-class), but it has always been thriving with music, night-life, and sexual entertainment.

Differences between gentrifying areas in London in terms of social mixity can be explained as a varying interplay between social, cultural and economic capital (Butler and Robson 2001). Take, for example, the recent and highly publicized protests in Shoreditch[2] around gentrification. The area has undeniably experienced a great deal of change in the past ten years - vintage clothing shops, expensive cocktail bars, designer pop-up stores, exotic street food stalls, and trendy coffee shops have replaced curry restaurants, small newsagents, whole sellers, and fabric shops that had catered for the large Bangladeshi and traditional working-class East End residents. Changes to the area can also be evidenced in the sharp increase of house prices; the property advisory firm CBRE suggests that house prices in Shoreditch have risen by 68 percent since 2008, with the average house now valued at $£ 723,000$. This is partly driven by the increasing number of businesses in the area, and in particular by the growing number of creative and tech companies that now account for 32 percent of offices in the area (compared to 12 percent in 2005). CBRE suggests that this increase has influenced the local area, with the number of shops, restaurants and pop-ups expanding, and makes clear that Shoreditch is a popular place to live, particularly for high-earning young adults under-35 (Jefford 2015).

Shoreditch has experienced what might be understood as 'hipsterification', and the local population has changed dramatically as increasing house prices and influx of tech companies force changes on long-established low-income residents. In many examples of gentrification, initial waves of settlement are often originated by artists or the creative classes (Florida 2003; Ley 2003; Matthews 2010) particularly attracted by cheaper housing in proximity of city centres, and this process can be easily seen in Shoreditch. However, we cannot blame hipsters alone for these changes, as the East End was part of a regeneration scheme that began with the Docklands in the 1980s, and was accelerated and expanded by the prospect of hosting the Olympics in 2012 (Davis and Thornley 2010). The socio-economic impact of this regeneration scheme has disproportionately affected local businesses (Raco and Tunney 2010), low-income residents, and migrant populations - all of whom have been facing direct or indirect residential displacement (Kennelly and Watt 2012; Watt 2013). Overall, in the East End, organic forms of gentrification by middle-class urbanites have been increasingly coupled with the intervention of large private developers who have sought capitalist opportunities in a neoliberal and insufficiently regulated housing market in London. The case of the East End is thus more complicated than just a 'hipsterification', and requires a more nuanced definition to understand the nature of these changes. This is however beyond the scope of this paper, and instead we use this as point of departure recognising the multifaceted nature of gentrification (Butler et al. 2006) to introduce our discussion on the type of gentrification taking place in Soho.

1.5 The past twenty years have brought substantial changes to Soho, but in contrast to areas in the East End, this process has not particularly been influenced by an influx of creative or young professionals moving into the area and displacing local residents and businesses; rather, this is a more obviously neoliberal and hegemonic form of gentrification that has been brought about by a handful of privately-owned companies, with one company in particular (Soho Estates) dominant in the (re)development of Soho, with many changes facilitated by Westminster City Council. In 2004, writing about the politics of the revanchist city, Phil Hubbard notes that Soho was already starting to experience social changes through processes of gentrification. Over a decade later, we argue that these attempts to gentrify Soho have intensified, with marginal and 'undesirable' groups being specifically targeted by the state and private capital to create a sanitized space.

1.6 Soho Estates, a private property entity, own more than 60 acres across Soho and Leicester Square and are estimated to be worth $£ 370$ million (Sandher 2012). With the help of Westminster City Council, Soho Estates have made a number of changes to the local area, including converting retail space into expensive residences for wealthy families (Economist 2015), and raising the rents of a number of businesses in an attempt to 'clean up' the area. Porn shops, burlesque venues, peep shows and strip clubs seem to be a particular focus for Soho Estates, with the chairman Steve Norris, saying: 'Our motto is: edgy but not seedy' (Economist 2015).

1.7 Not everyone welcomes these changes: groups such as Save Soho argue that the changes are being made without proper consultation with residents and local businesses, and are calling for measures to help stop the rapid changes that are being imposed from the top-down, but they are more concerned about preserving the creative industry in the area, rather than advocating for marginalized groups. This is particularly problematic as it is specifically marginalized groups that have long histories in the area that are being disproportionately targeted as a result of these changes. In 2013, for example, police raided a number of flats in Soho where sex workers are known to work, ostensibly to locate and 'rescue' victims of trafficking. While the police found no victims of 
trafficking, and there was no evidence that women were working illegally, many of the flats were still shut down, and sex workers who had worked in the area for many years were forced to leave. The English Collective of Prostitutes comments on this, and suggests that despite having the support of many local residents, the closure of the flats may have more to do with the gentrification being imposed by Soho Estates:

\begin{abstract}
The closures of sex workers' flats are opposed by many other Soho residents and businesses because if the "girls" go, the whole character of this historic area will be lost forever. But the speed and ease with which the development proposed by Soho Estates' Walkers Court was waved through the planning meeting, despite local opposition, is very worrying. When the two flats in Peters Street owned by Soho Estates are raided and closed by police, but the one flat owned by someone else remains open, questions must be asked about whether closures were aimed at smoothing the path towards gentrification (ECP 2014).
\end{abstract}

1.8 This raid was eerily reminiscent of a similar invasion by the police in the early 2000 s, where Westminster City Council sought to remove sex workers in the area by the use of compulsory purchase orders of properties they suspected were being used for prostitution. This coincided (not coincidentally) with raids by the Metropolitan Police that saw 31 women arrested in Soho on charges related to prostitution (Hubbard 2004). Sex workers and sex work venues are often the target of surveillance and regulatory measures, used in essence to 'clean up' urban centres, and as Hubbard, Matthews, and Scoular (2009) argue, devolving the regulation of such spaces to the private sector is increasingly common, suggesting the struggles over the right to sex in the city 'is thus a realm in which the economic, the political and the moral intermingle' (2009: 186).

1.9 This moral regulation can also be seen in other parts of Soho that are currently being sanitized, in particular Old Compton Street, which has been an important space in London for the LGBT community. Several gay bars, including Manbar and The Green Carnation have closed in the past year, and the gay venue Soho Yard is currently under threat of closure (Duffy 2015). Old Compton Street is one of the prime areas being 'redeveloped'[3], and a quick look through the current development projects being run by Soho Estates makes clear the sterilized ways in which their vision of Soho is being spatially branded[4], making way not for middleclasses, but for a hyper-wealthy elite that can rest assured that the 'sleaze' has been stripped away, and does not impinge on their ability to enjoy the 'edgy' delights of Soho.

1.10 In the heart of Soho, for example, wealthy elites can enjoy a night out at The Box, a venue that sits in the exact same space as the original Raymond Revue Bar on Walkers Court and offers sexy burlesque-style entertainment for those who can afford a table with a $£ 1000$ cover charge, or can sit at the bar to watch the performance for a cost of $£ 300$; we argue that such expensive forms of entertainment demonstrate the effects of change here, change which is meant to actively exclude all but the very rich from accessing sexual entertainment. It seems that the only difference between edgy and sleazy is the type of person who can afford to visit these spaces, rather than the nature of the entertainment itself.

1.11 Many forms of gentrification have been driven in part by some sort of organic processes of change, and while they can in some cases be rapid (as seen with the contested legacy of the Olympics), changes to areas usually occur over a number of years, or even decades. In the East End we can see that gentrification is also to be understood in light of the regeneration policies that aim to drastically change areas and often results in displacement (direct or indirect). The difference in Soho is with the absence of the more organic processes engendered by the settlement of middle-class populations attracted by cheaper housing in centrally located working class areas. Soho presents many of the features of gentrification with a growing retail industry of cafes and restaurants echoing other concerns in terms of food justice and gentrification (Anguelovski 2015) but it is artificially created, and as Hubbard, Matthews and Scoular (2009) argue, little more than the devolved ordering and civilizing of 'sleazy' areas to the private sector, which allows Westminster City Council to regulate Soho by proxy, through Soho Estates.

1.12 Soho presents a number of specificities that mark the gentrification happening there as worthy of further investigation and conceptualization. Lees, Slater and Wyly (2010) note the difficulty in trying to understand the complex, varied and multi-layered processes that contribute to gentrification, and highlight the political and ideological power of the term. In the case of Soho, it becomes even more salient to consider these different dimensions as they constitute the 'power-geometries' (Massey 2005) of the place. In problematising the issue of gentrification, Butler and Lees (2006) make a distinction between different social categories and argue that, in particular locations, gentrification has been strengthened and altered by a global elite. These 'super-gentrifiers' as they have described them, come into an already gentrified area replacing 'the previous "ordinary" professional middle-classes' (Butler and Lees 2006: 469). In Soho, gentrification is instead organized around the elite it is trying to attract presenting another case study in the diverse nature of gentrification. 
1.13 It is obvious that local authorities in Soho and in other parts of London are fundamentally failing to safeguard social and affordable housing, and equally allowing market forces to change areas rapidly with little consideration to residents, particularly those who may have less cultural and social capital and may be less able to voice their concerns in a way that 'matters'. Westminster City Council planning applications have come under scrutiny recently due to the lack of social housing included in new development proposals (Rees 2015), and it is clear that there are justified concerns about the ways in which the Council are safeguarding social and affordable housing for low-income residents in the area. The relationship, or lack thereof, between longstanding workingclass residents and gentrifying middle-classes has been documented in different areas of London and has at times been described as 'social tectonics' (Butler and Robson 2001). Comparing the more recent gentrification in Peckham in Southeast London, for example, to gentrification in Brixton in the late 1990s, Jackson and Butler (2015) identify a different form of social mix whereby in Peckham, sections of the middle-classes perceive themselves as more invested into the local area and distinguish themselves 'from a more mainstream middleclass, here identified with nearby sanitized East Dulwich' (Jackson and Butler 2015: 2361). Soho presents yet another form of 'social tectonics' whereby social, cultural and physical landscapes are transformed by neocapitalist agendas that hide or even make invisible the processes of change. This complicates our understanding of gentrification in Soho and its impact on local communities.

1.14 Beyond the aesthetics of gentrification that can be observed in other gentrified or gentrifying areas, the changes are the result of an impetus led by some of its largest landlords such as Soho Estates, facilitated (if not directly encouraged) by Westminster City Council. Indeed the Council has also played a key part by encouraging the privatization of social housing, increasingly turning commercial properties into residential properties and allocating a growing number of licenses to new bars and restaurants while clamping down on others such as betting shops and sex shops. Their aim is not to attract a middle-class demographic - rather, its residents are increasingly comprised of the privileged few. The changes in Soho are imposed without substantive or meaningful consultation, and its effects are almost immediate - we argue that the aim of Soho Estates and Westminster City Council is to clean up the area to make room for the über-wealthy and are fully aware of the ways in which they are sanitizing the city to ensure that the 'edgy-not-seedy' image is imposed. This is a heavily weighted form of gentrification that gives marginal communities little chance to oppose, and little time to collectively voice concerns or organize themselves. As such, we propose to define it as 'hegemonic gentrification', and distinguish this from other forms of gentrification in order to understand the different processes that underpin these changes, as well as to understand the different impacts 'hegemonic gentrification' may have on local communities. More broadly, it allows us to problematize these changes with regards to the 'right to the city', and to consider how super-gentrifiers not only displace certain 'undesirable' populations, but how the private sector is increasingly given carte blanche to alter social and spatial practices, impacting on notions of inclusive citizenship in the city.

\section{Notes}

For more information on this issue see a recent publication by the London School of Architecture available at https://issuu.com/thelondonschoolofarchitecture/docs/soho_book_issuu?e=24871939/30000297.

For an interesting perspective on gentrification protests in East London see a blog from Alex Rhys-

Taylor: http://www.gold.ac.uk/news/comment-the-cereal-killer-cafe--unboxing-a-moral-panic/ .

See the Kettners website which provide detailed plans of changes to properties on and near to Old Compton Street: http://www.kettners-soho.co.uk.

http://www.sohoestates.co.uk/\#!projects/c1dq3.

\section{References}

ANGUELOVSKI, I. (2015) 'Alternative Food Provision Conflicts in Cities: contesting food privilege, injustice, and whiteness in Jamaica Plain, Boston' Geoforum, 58: p. 184-194. [doi:10.1016/j.geoforum.2014.10.014] 
BUTLER, T. and Lees, L. (2006) 'Super-gentrification in Barnsbury, London: globalization and gentrifying global elites at the neighbourhood level', Transactions of the Institute of British Geographers, 31(4): p. 467-487. [doi:10.1111/j.1475-5661.2006.00220.x]

BUTLER, T. \& Robson, G. (2001) 'Social Capital, Gentrification and Neighbourhood Change in London: a comparison of three South London Neighbourhoods', Urban Studies, 38(12): p. 2145-2162. [doi:10.1080/00420980120087090]

DAVIS, J. \& Thornley, A. (2010), 'Urban Regeneration for the London 2012 Olympics: issues of land acquisition and Legacy', City, Culture and Society, (1): p. 89-98.

DUFFY, N. (2015). 'Yet another Soho gay bar could be facing closure'.Pink News (online) http://www.pinknews.co.uk/2015/01/23/yet-another-soho-gay-bar-could-be-facing-closure/Accessed 20 March 2016.

ECONOMIST (2015) 'So long, Soho'. The Economist (online) http://www.economist.com/news/britain/21637452londons-seediest-district-hints-some-ways-capital-changing-so-long-sohoAccessed 14 March 2016.

ENGLISH COLLECTIVE OF PROSTITUTES (2014). The Soho Raids: What really happened. http://prostitutescollective.net/2014/01/15/the-soho-raids-what-really-happened/ Accessed 20 March 2016.

FLORIDA, R. (2003) Cities and the Creative Class, City and Community, 2(1): p. 3-19 [doi:10.1111/15406040.00034]

HUBBARD, P. 2004. 'Cleansing the metropolis: sex work and the politics of zero tolerance',Urban Studies, 41(9): p. 1687-1702. [doi:10.1080/0042098042000243101]

HUBBARD, P., Matthews, R., and Scoular, J. 2009. 'Legal Geographies - Controlling Sexually Oriented Businesses: Law, Licensing and the Geographies of a Controversal Land Use'. Urban Geography, 30(2): p. 185-205. [doi:10.2747/0272-3638.30.2.185]

JACKSON, E. \& Butler, T. (2015) "Revisiting 'Social Tectonics': the middle-classes and social mix in gentrifying neighbourhoods, Urban Studies, 52(13): p. 2349-2365 [doi:10.1177/0042098014547370]

JEFFORD, K. (2015). 'House prices in City fringe areas of Shoreditch, Clerkenwell and Hoxton have surged by 62 per cent since 2008'. City A.M. (online) 7 December 2015.

http://www.cityam.com/230306/house-prices-in-city-fringe-areas-of-shoreditch-clerkenwell-and-hoxton-havesurged-by-62-per-cent-since-2008. Accessed 14 March 2016.

KENNELLY, J. \& Watt, P. (2012) 'Seeing through the eyes of marginally housed youth: changing places and the gentrification of East London' Visual Studies, 27(2): p. 151-160. [doi:10.1080/1472586X.2012.677496]

LEES, L. (2012). 'The geography of gentrification: Thinking through comparative urbanism',Progress in Human Geography, 36(2): p. 155-171. [doi:10.1177/0309132511412998]

LEES, L. Slater, T. and Wyly, E. (2010) The Gentrification Reader, London: Routledge

LEES, L. Slater, T. and Wyly, E. (2008) Gentrification, London: Routledge

LEY, D. (2003) 'Artists, Aestheticisation and the Field of Gentrification', Urban Studies, 40(12): p. 2527-2544. [doi:10.1080/0042098032000136192]

MASSEY, D. (2005) For Space. London: Sage Publication

MARCUSE, P. (2012) "Whose Right(s) to What City?" in Brenner, N., Marcuse, P. and Mayer, M. (eds), Cities for People, Not for Profit: Critical Urban Theory and the Right to the City, London: Routledge, p. 24-62

MATTHEWS, V. (2010) 'Aestheticizing Space: Art, Gentrification and the City' Compass Geography, 4(6): p. 660675. [doi:10.1111/j.1749-8198.2010.00331.x]

RACO, M. \& Tunney, E. (2010) 'Visibilities and Invisibilities in Urban Development: Small Business Communities and the London Olympics 2012', Urban Studies, 47(10): p. 2069-2091. [doi:10.1177/0042098009357351] 
REES, L. (2015) 'Westminster council to decide on plans for 105 flats with no social housingFitzrovia News (online) 15 April 2015. http://news.fitzrovia.org.uk/2015/04/15/westminster-council-to-decide-on-plansfor-105-flats-with-no-social-housing/Accessed 14 March 2016.

RIGHTMOVE (2016). http://www.rightmove.co.uk/property/Soho.htmIAccessed 15 May 2016.

SANDHER, H. 'Kings of Soho: James and Norris's Soho transformation', http://www.propertyweek.com/indepth/analysis-features/kings-of-soho-james-and-norriss-soho-transformation/5038644.articlelast accessed 7th June 2016

SCHMID, C. (2012) "Henri Lefebvre, The Right to the City, and the New Metropolitan Mainstream", in Brenner, N., Marcuse, P. and Mayer, M. (eds), Cities for People, Not for Profit: Critical Urban Theory and the Right to the City, London: Routledge, p. 42-62

WALKOWITZ, J. (2012) Nights Out - Life in Cosmopolitan London Yale University Press.

WATT, P. (2013) ' "It's not for us" Regeneration, the 2012 Olympics and the Gentrification of East London',City, 17(1): p. 99-118. [doi:10.1080/13604813.2012.754190] 